Article

\title{
Transformation of S-Bearing Minerals in Organic Matter-Rich Sediments from a Saline Lake with Hydrothermal Inputs
}

\author{
Gabriel Ricardo Cifuentes ${ }^{1}$, Juan Jiménez-Millán ${ }^{2, *}$, Claudia Patricia Quevedo ${ }^{1}$ and \\ Rosario Jiménez-Espinosa ${ }^{2}$ (D) \\ 1 Faculty of Science and Engineering, Water Resources Research Group, University of Boyacá, \\ Campus Tunja 15003, Colombia; grcifuentes@uniboyaca.edu.co (G.R.C.); \\ patriciaquevedo@uniboyaca.edu.co (C.P.Q.) \\ 2 Department of Geology and CEACTEMA, University of Jaén, Campus Las Lagunillas, 23071 Jaén, Spain; \\ respino@ujaen.es \\ * Correspondence: jmillan@ujaen.es
}

Received: 17 May 2020; Accepted: 5 June 2020; Published: 9 June 2020

check for updates

\begin{abstract}
Geothermal systems can provide significant amounts of hydrothermal sulfur to surface waters, increasing salinity and avoiding some of the common anthropic uses. The objective of this study was to investigate the sedimentary neoformation of S-bearing phases in organic matter-rich sediments from a saline lake with hydrothermal inputs (Sochagota Lake, Colombia). Detrital kaolinite and quartz are the main minerals of the materials deposited in the Sochagota Lake. Neoformed clay minerals (illite and illite-dioctahedral vermiculite mixed layers) are concentrated in the central and northern part of the lake in sediments with high organic matter content. The most organic matter-rich materials are characterized by S-bearing minerals: mackinawite, pyrite, and elemental sulfur $\left(\mathrm{S}^{\circ}\right)$. FESEM, high-resolution transmission electron microscopy (HRTEM), EDS, and Raman microspectrometry have revealed the presence of cell-shape aggregates of mackinawite nanoparticles filling the inner part of plant fragments, indicating that microorganisms were involved in the hydrothermal sulfur uptake. The alteration of mackinawite in free sulfide excess environment produced the formation of framboidal pyrite. The evolution to conditions with the presence of oxygen favored the formation of complex $S^{\circ}$ morphologies.
\end{abstract}

Keywords: Sochagota Lake; hydrothermal sulfur; sedimentary sulfur uptake; mackinawite; pyrite; elemental sulfur

\section{Introduction}

The presence of sulfur as an important component is widely extended in many hydrothermal systems controlling the geochemistry and distribution of most of the trace elements in geothermal systems [1,2]. In geothermal systems, the presence of alkaline hot springs is very frequently found as surface waters, representing the composition of the geothermal reservoir [3]. The boiling of the reservoir can produce fluids enriched in volatile gases such as $\mathrm{CO}_{2}$ and $\mathrm{H}_{2} \mathrm{~S}$, which proportion can change depending on the degree of boiling $\left(\mathrm{H}_{2} \mathrm{~S}\right.$ content increases with increasing of boiling). $\mathrm{H}_{2} \mathrm{~S}$ hydrothermal fluids mix with non-thermal surface waters producing $\mathrm{SO}_{4}{ }^{2-}$-rich waters due to the oxidation of the hydrothermal $\mathrm{H}_{2} \mathrm{~S}[1,4]$. Spring discharges of $\mathrm{SO}_{4}{ }^{2-}$-rich fluids may alter the surface waters, producing important environmental effects in downstream waters, e.g., increasing salinity and avoiding some of the anthropic uses of the waters. The presence of natural or constructed lakes that accumulate this type of waters generates hydrologically restricted environments. Under tropical conditions, strong eutrophication [5,6] favors the deposit of organic matter-rich materials where the 
interaction with saline fluids and organic activity catalyze mineral reactions in the sediments [7]. Microbial redox reactions involving $S$ compounds can control some mineral authigenic sedimentary processes in these environments [8-10]. These reactions are commonly influenced by the formation of sulfide minerals. Rickard and Luther [11] exhaustively reviewed the chemistry of iron sulfides. The Fe monosulfide resulting from the precipitation of $\mathrm{Fe}^{2+}$ and $\mathrm{S}^{2-}$ is mackinawite (see, e.g., [12]). It precipitates as unstable tetragonal particles that transform to ordered crystals. Mackinawite is transformed through different pathways, according to $\mathrm{O}_{2}$ and $\mathrm{H}_{2} \mathrm{~S}$ concentrations, to greigite $\left(\mathrm{Fe}_{3} \mathrm{~S}_{4}\right)$, pyrite $\left(\mathrm{FeS}_{2}\right)$, elemental sulfur $\left(\mathrm{S}^{\circ}\right)$, and ferric oxides and hydroxides. $\mathrm{H}_{2} \mathrm{~S}$ concentrations in sedimentary environments under low-temperature conditions are associated with the activity of the sulfate-reducing microorganisms [13]. Some studies (e.g., [14]) indicated that mackinawite and greigite are infrequently conserved in the sedimentary rocks, but its formation can be controlled by microorganisms and they possibly have a critical reactive function in the current biogeochemical cycles of Fe and S. Among sulfide minerals, pyrite is characterized by its high stability and abundance [13]. Recent research [15] has indicated the importance of the sulfur biogeochemical cycle of native sulfur $\left(\mathrm{S}^{\circ}\right)$, which is produced by oxidation reactions (chemical or biological) of other S-bearing phases with lower oxidation state.

This study aims to investigate the sedimentary neoformation of S-bearing phases in organic matter-rich sediments from a saline lake with hydrothermal inputs. High-resolution microscopy techniques, such as field emission scanning electron microscopy (FESEM), high-resolution transmission electron microscopy (HRTEM)), coupled to high spectral resolution techniques, such as energy dispersive X-ray spectrometry (EDX) and Raman spectroscopy, were used in a fine-scale characterization to reveal the processes involved in the sedimentary uptake and transformation of the hydrothermal S.

\section{Materials and Methods}

\subsection{Study Site}

The Sochagota Lake is located in the Paipa province (Boyacá department, Colombia) (Figure 1a,b). This lake has, mainly, a recreational use. The surface area of the lake is $1.8 \mathrm{~km}^{2}$ and the deepest point is $3.20 \mathrm{~m}$. It is an artificial lake on a previous natural wetland forming a small endorheic basin in the lower course of the Salitre River (Paipa), a tributary of the Chicamocha River.
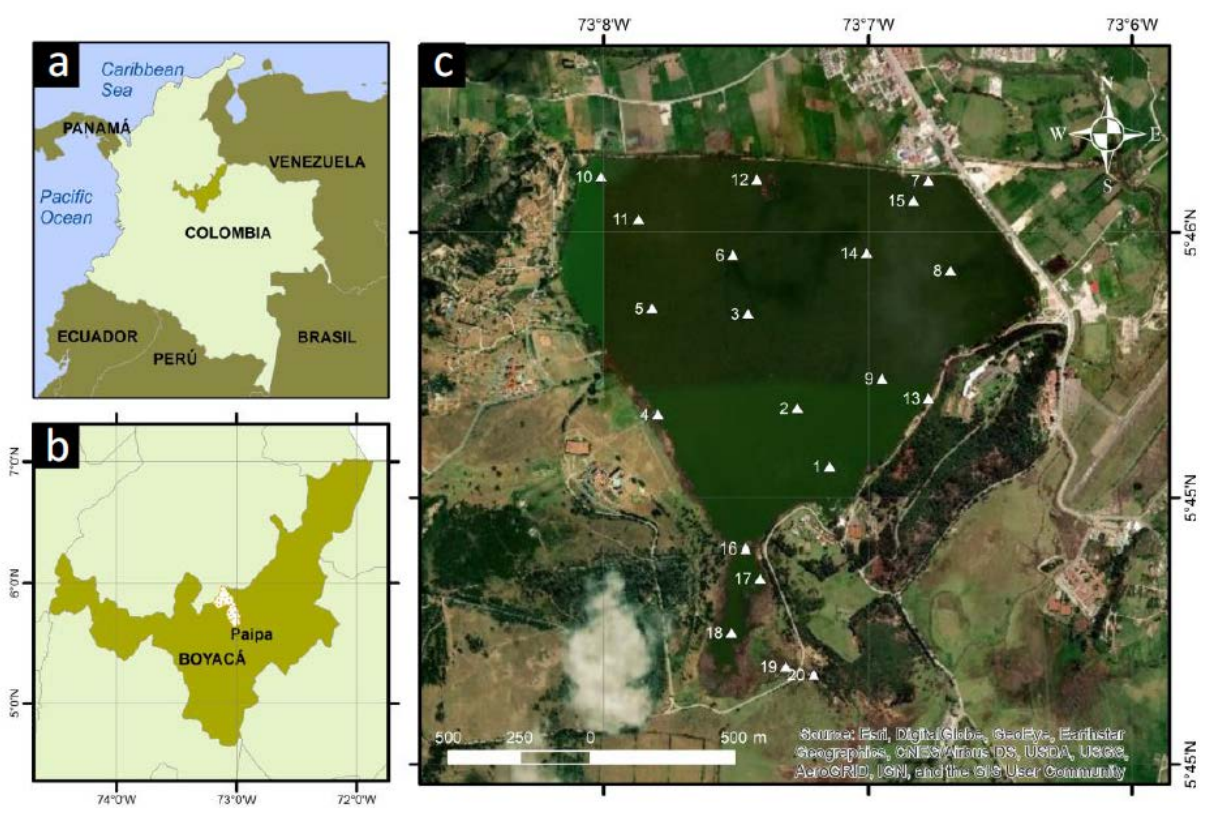

Figure 1. Geographical setting of the study area and sampling location. (a) Global context of the area; (b) Local situation in Colombia; (c) Location of the sampling points 1 to 20 at the Sochagota Lake. 
The average annual temperature in Paipa is $14.4^{\circ} \mathrm{C}$. The average rainfall is $911 \mathrm{~mm} /$ year, with this precipitation well distributed throughout the year. The climate is subtropical highland (altitude, $2496 \mathrm{~m}$ ) oceanic (classified as Cfb by the Köppen system).

From the geological perspective, the Sochagota Lake is situated in the main geothermal area of the Andean Cordillera in the Colombian territory, with hydrothermal systems located mainly around the volcanoes of the Andean Cordillera in the Colombian territory. These volcanoes predominantly intrude cretaceous siliceous sedimentary rocks (conglomerates, sandstones, shales, and claystones) (Figure 2). The presence of evaporitic rocks or other types of salt-bearing rocks has not been described in the stratigraphic column of the area. To the south of the small endorheic basin of the Sochagota Lake outcrop the materials of one of these volcanoes, the Paipa volcano [16], which is an eroded explosive volcanic building formed by acid pyroclastic deposits (alkaline rhyolites and trachyandesites) of Pliocene-Pleistocene age. This structure includes a collapsed caldera of $3 \mathrm{~km}$ diameter that has several hydrothermal vents. The presence of these materials may be related to the heat source of the intense geothermal system in the area as well as to the presence of S-bearing materials. A high-temperature geothermal system related to a magmatic heat source has been proposed for the area [17]. The heat upflow is controlled by deep faults and a shallow mixing process producing a highly mineralized sodium-sulfate water that hides the chemical composition of the deep reservoir fluid.

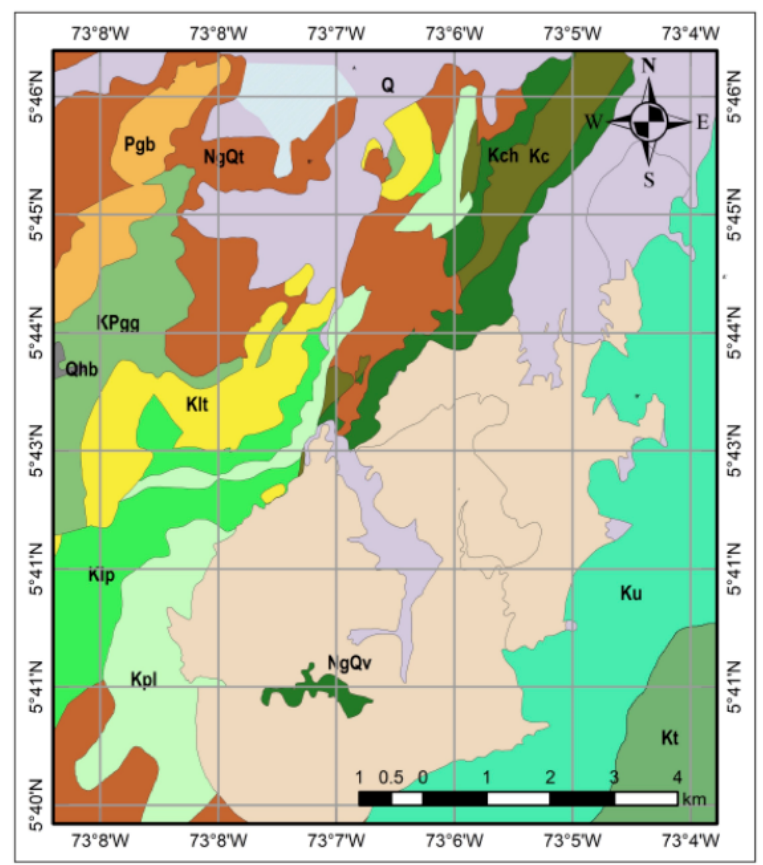

$\mathrm{NgQv}$ Neogene-Quaternary volcanic rocks Pyroclastic alkaline rhyolites and trachyandesites

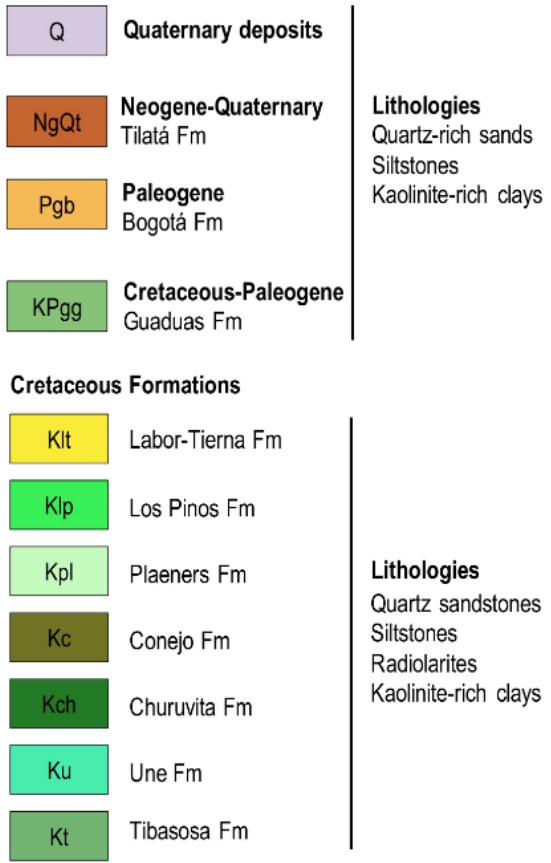

Qhb Quaternary hydrothermal breccias

Figure 2. Geological map of the Sochagota Lake Basin. The lake does not receive sediments from the north area. Modified from Reference [16].

The Sochagota Lake stores natural hydrothermal saline waters [18] mixed with rain surface waters. Table 1 shows that lake waters have high electrical conductivity $(2440 \mu \mathrm{S} / \mathrm{cm})$ and $\mathrm{pH}(9.27)$. These waters are enriched in $\mathrm{SO}_{4}{ }^{2-}(2165 \mathrm{mg} / \mathrm{L}), \mathrm{Na}^{+}(1493 \mathrm{mg} / \mathrm{L})$, and $\mathrm{K}^{+}(280 \mathrm{mg} / \mathrm{L})$. The isotopic composition of the water samples is characterized by mean values of $6.4 \%$ for $\delta^{34} \mathrm{~S}$ and 8.1 for $\delta^{18} \mathrm{O}$ [19]. The isotope contents (see, e.g., $[20,21]$ ) and the absence of evaporitic deposits in the geological context strongly suggest the hydrothermal origin of the $S$ responsible for the high salinity of the lake. 
Table 1. Average physical-chemical parameters of the Sochagota Lake waters from Reference [19].

\begin{tabular}{cc}
\hline Physical-Chemical Parameters and Units & Average Values \\
\hline $\mathrm{Cl}^{-}(\mathrm{mg} / \mathrm{L})$ & 672.3 \\
$\mathrm{SO}^{2-}{ }_{4}(\mathrm{mg} / \mathrm{L})$ & 2165.0 \\
$\mathrm{HCO}^{-}(\mathrm{mg} / \mathrm{L})$ & 204.2 \\
$\mathrm{CO}^{2-}{ }_{3}(\mathrm{mg} / \mathrm{L})$ & 1.5 \\
$\mathrm{NO}^{-}(\mathrm{mg} / \mathrm{L})$ & 314.9 \\
$\mathrm{Na}^{+}(\mathrm{mg} / \mathrm{L})$ & 1493.1 \\
$\mathrm{Mg}^{2+}(\mathrm{mg} / \mathrm{L})$ & 9.1 \\
$\mathrm{Ca}^{2+}(\mathrm{mg} / \mathrm{L})$ & 55.5 \\
$\mathrm{~K}^{+}(\mathrm{mg} / \mathrm{L})$ & 280.7 \\
$\mathrm{pH}$ & 9.27 \\
E.C. $(\mu \mathrm{S} / \mathrm{cm})$ & 2440.0 \\
Temperature $\left({ }^{\circ} \mathrm{C}\right)$ & 22.0 \\
\hline
\end{tabular}

E.C. Electrical conductivity.

The sediments were sampled from 20 points in a grid covering the entire area of the lake (Figure 1c). A standard stainless Shelby tube was used for sampling, and cores up to $50 \mathrm{~cm}$ deep were obtained. Coring polypropylene tubes with samples were capped at top and bottom with silicone rubber preserved in frozen tubes with dry ice at $-80{ }^{\circ} \mathrm{C}$, included in closed polyethylene bags that were transported to the laboratory until further processing. The extracted cores were divided into two sections: (a) 0-25 cm depth segment (samples ending with $-\mathrm{s}$ in Table 2) and (b) 25-50 cm segment (samples ending with $-\mathrm{p}$ in Table 2).

Table 2. Content in inorganic carbon (IC), total organic carbon (TOC), and total carbon from the materials deposited in the Sochagota Lake. *: 0-25 cm core segment; **: $25-50 \mathrm{~cm}$ core segment; ***: $0-50 \mathrm{~cm}$ core segment. Standard deviation is indicated in parenthesis.

\begin{tabular}{|c|c|c|c|}
\hline Sample & IC (\%) & TOC (\%) & Total C (\%) \\
\hline $1 p * *$ & $0.149(0.01)$ & $9.15(0.04)$ & 9.30 \\
\hline $1 s$ * & $0.142(0.01)$ & $4.11(0.02)$ & 4.25 \\
\hline $2 p * *$ & $0.269(0.03)$ & $1.01(0.01)$ & 1.28 \\
\hline $2 s *$ & $0.176(0.01)$ & $1.17(0.01)$ & 1.34 \\
\hline $3 p * *$ & $0.290(0.02)$ & $1.88(0.02)$ & 2.17 \\
\hline $3 s *$ & $0.188(0.01)$ & $1.74(0.01)$ & 1.93 \\
\hline $4 p^{* *}$ & $0.161(0.01)$ & $0.996(0.01)$ & 1.16 \\
\hline $4 s^{*}$ & $0.090(0.01)$ & $2.01(0.01)$ & 2.10 \\
\hline $5 p * *$ & $0.131(0.01)$ & $3.04(0.03)$ & 3.18 \\
\hline $5 s *$ & $0.121(0.01)$ & $2.51(0.03)$ & 2.63 \\
\hline $6 p * *$ & $0.123(0.02)$ & $11.1(0.01)$ & 11.20 \\
\hline $6 s *$ & $0.142(0.01)$ & $3.59(0.04)$ & 3.73 \\
\hline $\mathbf{M} 7 * * *$ & $<0.100$ & $1.16(0.01)$ & 1.24 \\
\hline $7 p^{* *}$ & $0.253(0.01)$ & $1.41(0.01)$ & 1.66 \\
\hline $7 s *$ & $0.229(0.01)$ & $1.21(0.01)$ & 1.43 \\
\hline M8 *** & $<0.10(0.01)$ & $1.25(0.03)$ & 1.33 \\
\hline $8 p * *$ & $0.181(0.01)$ & $2.12(0.01)$ & 2.30 \\
\hline $8 s *$ & $0.264(0.01)$ & $2.26(0.01)$ & 2.52 \\
\hline M9*** & $<0.100$ & $2.10(0.01)$ & 2.11 \\
\hline $9 p^{* *}$ & $1.26(0.03)$ & $0.66(0.01)$ & 1.93 \\
\hline $9 s$ * & $0.683(0.02)$ & $0.62(0.01)$ & 1.31 \\
\hline $10 p * *$ & $0.199(0.01)$ & $3.64(0.04)$ & 3.84 \\
\hline $10 s *$ & $0.194(0.01)$ & $3.18(0.02)$ & 3.38 \\
\hline $11 p * *$ & $0.195(0.01)$ & $1.52(0.01)$ & 1.72 \\
\hline $11 s *$ & $0.200(0.01)$ & $1.57(0.01)$ & 1.77 \\
\hline $12 p * *$ & $0.206(0.01)$ & $1.24(0.01)$ & 1.45 \\
\hline $12 s *$ & $0.141(0.01)$ & $1.80(0.01)$ & 1.94 \\
\hline
\end{tabular}


Table 2. Cont.

\begin{tabular}{|c|c|c|c|}
\hline Sample & IC (\%) & TOC (\%) & Total C (\%) \\
\hline $13 p$ ** & $0.216(0.01)$ & $1.27(0.01)$ & 1.48 \\
\hline $13 s^{*}$ & $0.957(0.01)$ & $0.37(0.01)$ & 1.33 \\
\hline $\mathbf{M 1 4} * * *$ & $<0.10$ & $0.96(0.01)$ & 0.96 \\
\hline $14 p * *$ & $0.218(0.01)$ & $3.45(0.04)$ & 3.67 \\
\hline $14 s *$ & $0.149(0.01)$ & $2.24(0.01)$ & 2.38 \\
\hline $15 p * *$ & $0.218(0.01)$ & $1.73(0.01)$ & 1.94 \\
\hline $15 s *$ & $0.188(0.01)$ & $1.59(0.01)$ & 1.78 \\
\hline $16 p^{* *}$ & $0.408(0.01)$ & $0.48(0.01)$ & 0.89 \\
\hline $17 p^{* *}$ & $0.156(0.01)$ & $0.64(0.01)$ & 0.80 \\
\hline $17 s *$ & $0.309(0.01)$ & $0.31(0.01)$ & 0.62 \\
\hline $18 p$ ** & $0.212(0.01)$ & $4.35(0.05)$ & 4.56 \\
\hline $18 s$ * & $1.180(0.02)$ & $0.29(0.01)$ & 1.48 \\
\hline $19 p * *$ & $0.257(0.01)$ & $1.64(0.02)$ & 1.89 \\
\hline $19 s *$ & $0.137(0.01)$ & $1.78(0.01)$ & 1.89 \\
\hline $\mathbf{M} 20 * * *$ & $<0.100$ & $0.69(0.01)$ & 0.70 \\
\hline $20 p^{* *}$ & $0.158(0.01)$ & $1.79(0.02)$ & 1.95 \\
\hline $20 s *$ & $0.189(0.01)$ & $2.59(0.03)$ & 2.78 \\
\hline
\end{tabular}

\subsection{Methods}

We prepared oriented aggregates (whole sample and $<2 \mu \mathrm{m}$ fraction) to obtain X-ray diffraction (XRD) data. Samples were previously washed with ultrapure water to remove salts [22]. Oriented aggregates were obtained by sedimentation in a glass. Centrifugation was used to separate the $<2 \mu \mathrm{m}$ fraction. Ethylene glycol and heating treatments at $400{ }^{\circ} \mathrm{C}$ and $550{ }^{\circ} \mathrm{C}$ were carried out to identify expandable clay minerals.

The diffractograms were obtained in a PANalytical X'Pert Pro diffractometer $(\mathrm{CuK} \alpha$ radiation, $45 \mathrm{kV}, 40 \mathrm{~mA}$ ), equipped with an $\mathrm{X}^{\prime}$ Celerator solid-state linear detector, which was used to obtain the diffraction patterns $\left(0.008^{\circ} 2 \theta\right.$ step increment and $10 \mathrm{~s} /$ step of counting time) (CICT, University of Jaén, Jaén, Spain). A scan between $3^{\circ}$ and $62^{\circ} 2 \theta$ was carried on the air-dried samples, while for the treated samples, the scan was done between $2^{\circ}$ and $30^{\circ} 2 \theta$ to help with the identification of clay minerals [22].

We used polished sections to obtain back-scattered electrons (BSE) images and tridimensional sediment fragments to acquire secondary electron (SE) images in a field emission scanning electron microscope (FESEM, Merlin Carl Zeiss of the CICT of the University of Jaén, Jaén, Spain). Polished samples used for BSE images were previously impregnated under vacuum with a polyester resin [23]. BSE images were acquired at $15 \mathrm{kV}$ with a working distance of $8 \mathrm{~mm}$ using an AsB detector, whereas $\mathrm{SE}$ images were acquired at $15 \mathrm{kV}$ using conventional and in-lens detectors, according to Reference [24]. These images provided the information for a textural and microchemical characterization.

The nanometric characterization was carried out by high-resolution transmission electron microscopy (HRTEM) following the experimental procedure indicated by Nieto and collaborators [25] in two electron microscopes at the CIC of the University of Granada (FEI TITAN and the Philips CM20) (Granada, Spain). Au and Cu grids were used to prepare samples from alcohol or distilled water of sample particles dispersion.

A FESEM with a Raman spectrometer (CIC, University of Granada, Granada, Spain) was used for the Raman spectrometry following the experimental procedure indicated by Guerra and Cardell [26] (Zeiss Supra 40Vp FESEM with a Renishaw spectrometer In Via fitted with a Nd:YAG $532 \mathrm{~nm}$ laser and a near-infrared diode $785 \mathrm{~nm}$ laser, maximum powers of $500 \mathrm{~mW}$ and $100 \mathrm{~mW}$, respectively, coupled to a Peltier-cooled CCD detector and single-grating monochromators, 1200 and 1800 lines $\mathrm{mm}^{-1}$ ).

Total organic carbon (TOC) was measured after preparing five replicate samples for every core segment using high-temperature $\left(720^{\circ} \mathrm{C}\right)$ catalytic oxidation (Pt-alumina) on a Shimadzu TOC-V CSH Total Organic Carbon Analyzer [27] from the IRNAS at CSIC-Sevilla (Sevilla, Spain). Sediment samples were precisely weighed $(2-3 \mathrm{mg} \pm 0.01 \mathrm{mg})$ on silver capsules. Analytical replication of reference 
material (PACS-2) was run every 10 samples. The limit of quantification was calculated as $0.03 \%$. Standard deviation for every core segment is indicated in Table 1.

\section{Results}

The materials accumulated in the Sochagota Lake are microlaminated sediments. There are important differences between the materials sampled in the south part of the lake and those from the central and north areas.

Samples from the south part are light-colored and compact. XRD analyses reveal the presence of high amounts of kaolinite, quartz, and feldspars (Figure 3a). Scanning electron microscope images show that quartz and feldspar appear as large sub-idiomorphic crystals sized from 100 to $800 \mu \mathrm{m}$ (Figure 4a). Feldspar crystals are characterized by the presence of very altered surfaces (Figure $4 b$ ). Acid volcanic glass particles very rich in microvesicles, whose size varies between 2 and $10 \mu \mathrm{m}$, can also be observed.

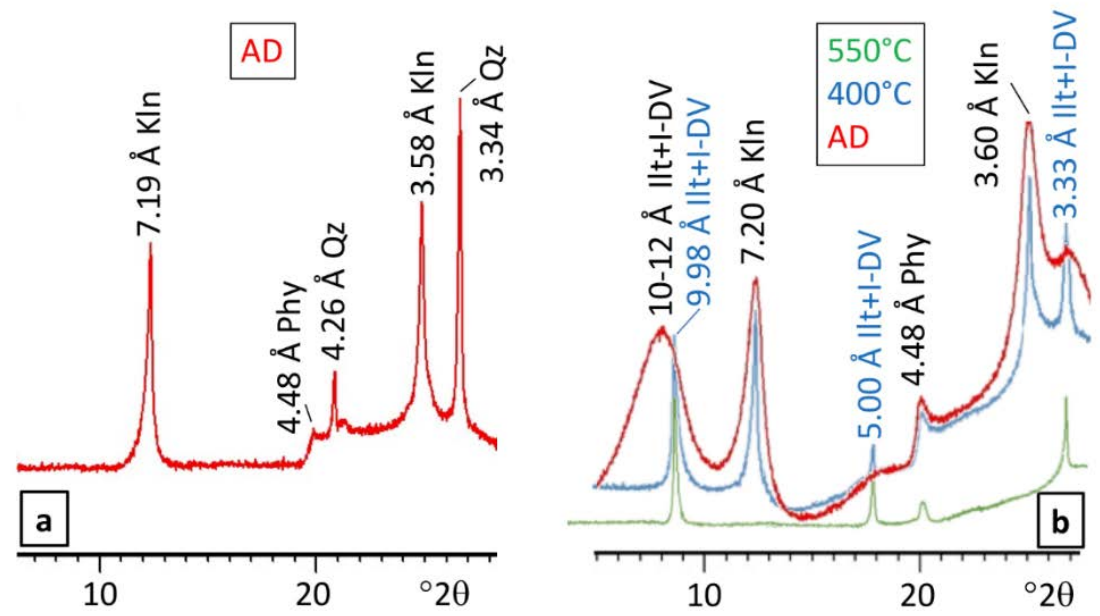

Figure 3. XRD diagrams of air-dried oriented aggregates from samples of the Sochagota Lake. (a) Representative sample from the south part of the lake (segment 0-25 cm depth). (b) Representative sample from the central and north areas (segment 25-50 cm depth). Kln: kaolinite, I-DV: illitedioctahedral vermiculite mixed layers, Ilt: illite, Qz: quartz. Red: air-dried (AD) pattern; blue: $400{ }^{\circ} \mathrm{C}$ heated pattern; green: $550{ }^{\circ} \mathrm{C}$ heated pattern.
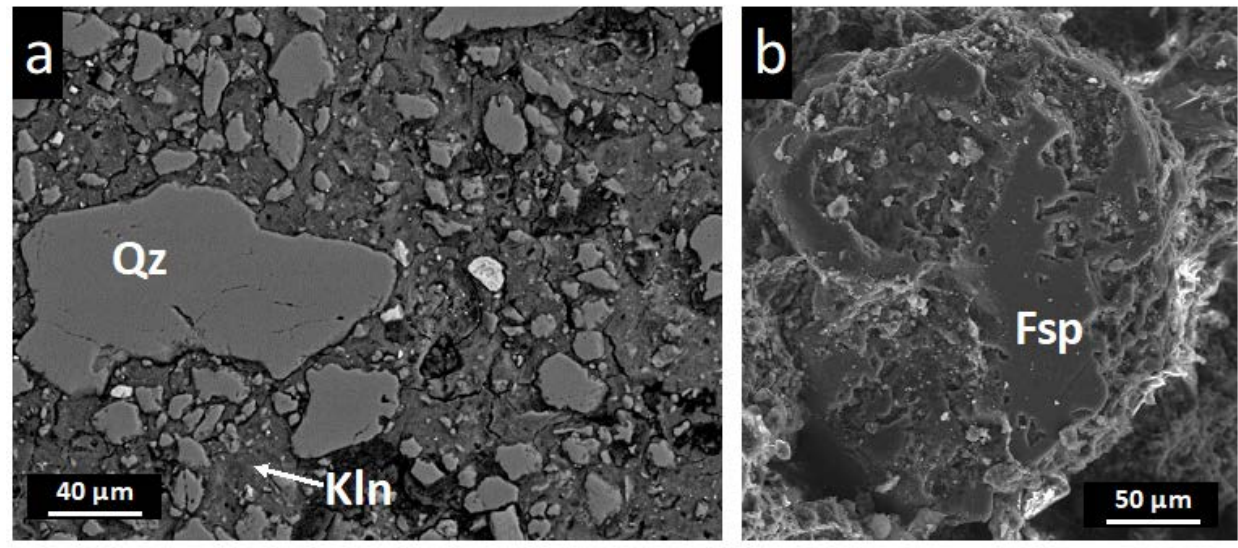

Figure 4. FESEM images of samples from the south part of the lake. (a) back-scattered electrons (BSE) image of crystals of quartz in a kaolinite-rich matrix (sample from segment 25-50 cm depth); (b) SE image of feldspar crystal with altered surface (sample from segment 0-25 cm depth). Kln: kaolinite, Qz: quartz, Fsp: feldspar. 
On the other hand, sediments from the central and north areas are very fine grain sized. X-ray diffraction analysis shows that these materials are frequently enriched in clay minerals (Figure 3b), of which mineral assemblage is made of illite, illite-dioctahedral vermiculite mixed layers, and kaolinite (Figure 5a) [28]. FESEM images show that the clay-rich matrix of the sediments is often crossed by elongated plant rests, diameter of which can reach up to $50 \mu \mathrm{m}$ (Figure $5 \mathrm{~b}$ ).
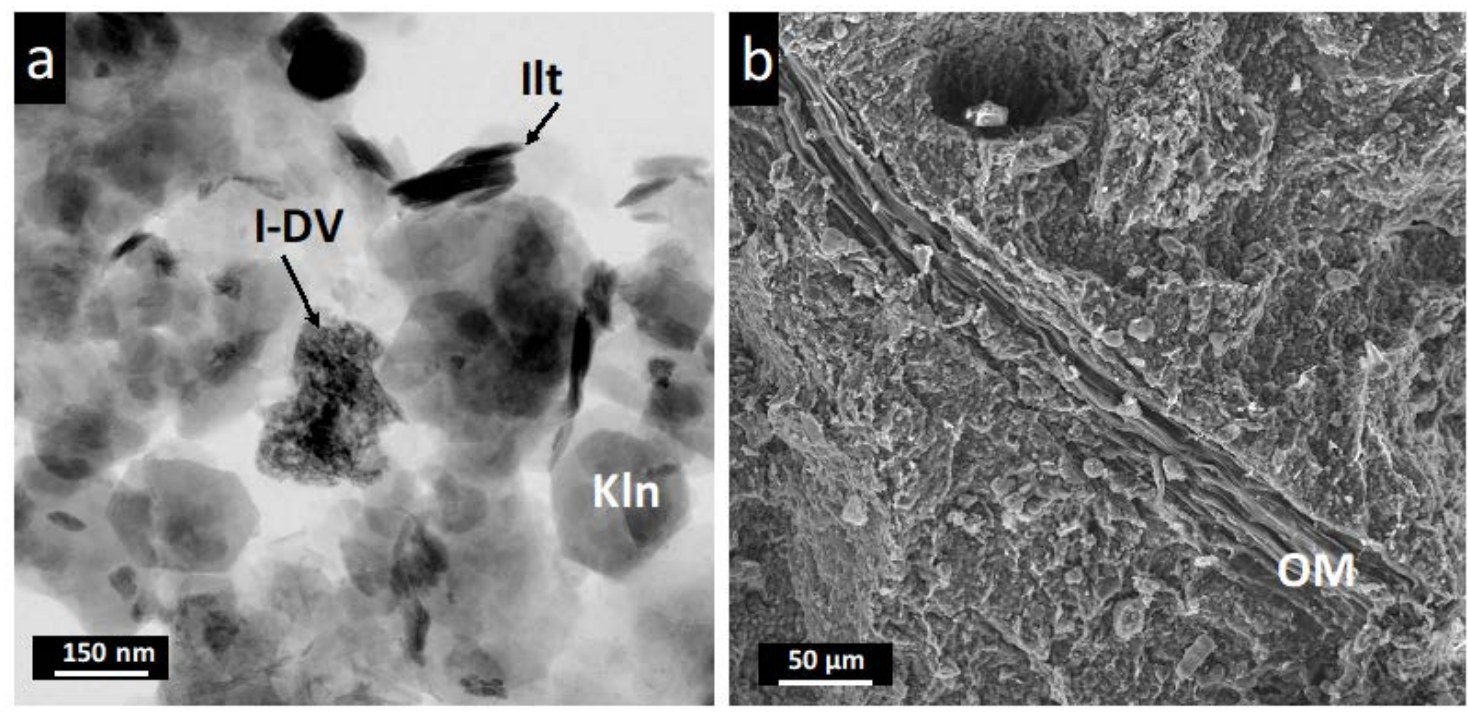

Figure 5. FESEM images of samples from the north part of the lake. (a) HRTEM image showing the mineral assemblage made of illite, illite-dioctahedral vermiculite mixed layers, and kaolinite (sample from segment 0-25 cm depth); (b) FESEM-SE image showing the clay-rich matrix of the sediments crossed by elongated plant rests (sample from segment $25-50 \mathrm{~cm}$ depth). Kln: kaolinite, Ilt: illite, I-DV: illite-dioctahedral vermiculite mixed layers, OM: organic matter.

Sulfur-bearing minerals are especially concentrated in materials rich in organic matter from the central and north areas. Figures 6 and 7 show FESEM and HRTEM micrographs, as well as EDX and micro-Raman spectra of sulfur-containing minerals from the Sochagota Lake sediments.

Pyrite is the most abundant S-bearing mineral in the organic matter-rich materials. Microcrystals and pyrite spherules of around $500 \mathrm{~nm}$ appear between the micropores of the sediment (Figure 6a). EDX microanalyses of these grains show a Fe:S ratio close to 2 . The aggregation of pyrite crystals produces less than $10 \mu \mathrm{m}$ sized framboids (Figure $6 \mathrm{~b}-\mathrm{d}$ ). Accumulations of framboidal pyrite is especially important in areas rich in organic matter remains (Figure 6e). Near these pyrite-rich zones appear individual grains of elemental $S$ of around $10 \mu \mathrm{m}$ in size (Figure $6 \mathrm{f}$ ) and S-aggregates formed by microfilaments and micro-spherules that generate a vesicular texture (Figure $6 \mathrm{~g}$ ). Raman spectra of these regions (Figure 6h) allow the identification of pyrite, with peaks at 344 and $379 \mathrm{~cm}^{-1}$ [29] and elemental $S$ with peaks at 152 and $220 \mathrm{~cm}^{-1}$ [30]. Weak mackinawite peaks $\left(208,260\right.$, and $\left.298 \mathrm{~cm}^{-1}\right)$ were also observed [31].

In contrast, other $\mathrm{Fe}^{2+}$ sulfides were detected in the inner part of some cores enriched in organic matter (Figure 7). EDX analyses indicates that its Fe-S atomic ratio is close to 1 for some of these minerals filling plant fragments, which corresponds to the mackinawite composition FeS (Figure 7a,b).

Detailed high magnification images of the inner part of the plant fragments revealed the presence of clusters of fine FeS nanoparticles (around $80 \mathrm{~nm}$ ) forming aggregates, which shape and size $(1-2 \mu \mathrm{m})$ is similar to the bacterial cell morphology (Figure 7c-e). HRTEM images also show scattered extracellular nanoparticles (Figure 7f). EDX microanalyses of nanoparticles from the HRTEM study also shows the same Fe:S ratio. Raman spectra of the FeS minerals filling plant rests confirmed the presence of mackinawite with an important peak at $298 \mathrm{~cm}^{-1}$, a secondary one at $208 \mathrm{~cm}^{-1}$, and a very weak peak at $260 \mathrm{~cm}^{-1}$ (Figure 7g) [31]. Greigite was not identified in any samples. 

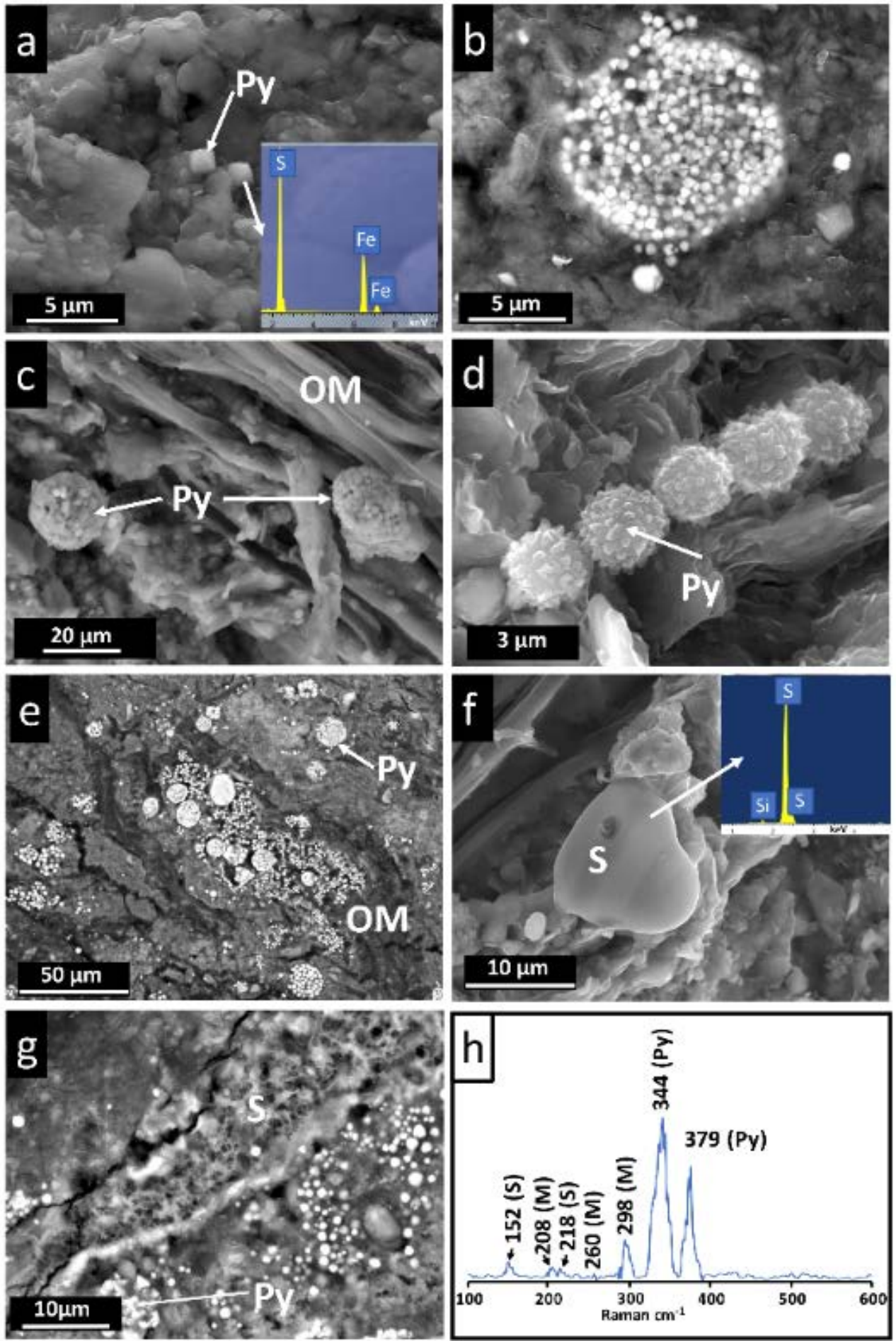

Figure 6. Electron microscope image and spectroscopy data (EDS and Raman) of pyrite and $\mathrm{S}^{\circ}$ in the organic matter-rich materials of the lake (samples from segments 0-(samples from segments $25-50 \mathrm{~cm}$ depth, except for a) $25 \mathrm{~cm}$ depth, except for a). (a) SE image of microcrystals of pyrite between the micropores of the sediment; (b), (c) and (d) SE images of pyrite framboids; (e) BSE image of an accumulation of framboidal pyrite near organic matter rests; (f) SE image of an individual grain of native sulfur near pyrite-rich zones; (g) BSE image of a S-aggregate formed by microfilaments that generate a vesicular texture; (h) Raman spectrum of pyrite-rich region. Py: pyrite, OM: organic matter, S: elemental sulfur, M: mackinawite. 

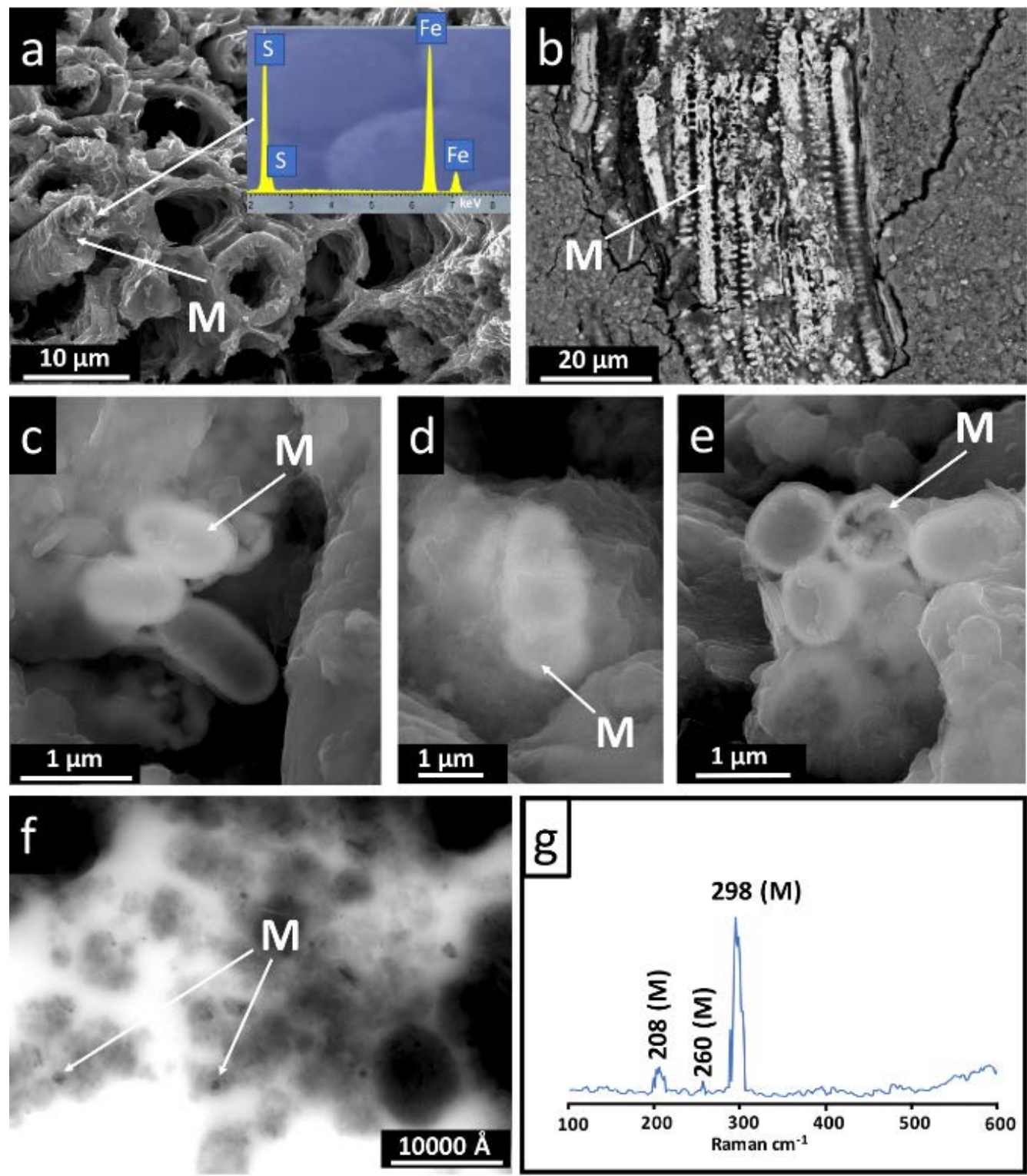

Figure 7. Electron microscope image and spectroscopy data (EDS and Raman) of mackinawite in the organic matter-rich materials of the lake (samples from segments $25-50 \mathrm{~cm}$ depth, except for a). (a) and (b) FeS filling plant fragments in a SE image (a) and in a BSE image (b); EDX analysis indicates that its Fe-S atomic ratio is close to 1; (c), (d) and (e) Detailed high magnification SE images of the inner part of the plant fragments revealing FeS nanoparticles aggregates with bacterial cell morphology; (f) HRTEM image showing scattered FeS nanoparticles; (g) Raman spectrum of the FeS minerals filling plant rests confirming the presence of mackinawite. M: mackinawite.

Regarding the organic matter content, TOC in the sediments oscillated from $0.28 \%$ to $11.1 \%$ (Table 2). The lowest concentrations were located in materials rich in kaolinite, quartz, and feldspars formed in the south part of the lake, near the El Salitre hydrothermal input, and where plant vegetation is scarce. The highest concentrations of total organic carbon were found in the materials rich in 2:1 phyllosilicates (illite-dioctahedral vermiculite mixed layers (I-DV) and illite) at the central and northern part of the lake, frequently close vegetation rich zones. These fine sized sediments have the highest contents of sulfide minerals. 


\section{Discussion}

The relationship between detrital materials, hydrothermal input, high organic matter content, and S-containing mineral precipitation occurring in the Sochagota lake was evaluated in this study.

\subsection{Detrital Minerals and Neoformed Clay Minerals}

The results of this study revealed that the materials formed at the Sochagota Lake exhibited significant differences in the grain size, mineral assemblage, and organic matter content according to the distance from the entrance of the hydrothermal inputs (El Salitre). From the entrance to the inner portion and the northern border of the lake, the amount of fine particles of clay minerals (illite and mixed-layer clay mineral) increases. The formation of illite and I-DV was occurred during the strong interaction of the sediments with the saline water-pore under the reduced conditions provided by the high content in organic matter [32]. Similar illitization processes in other saline and organic matter-rich environments, such as those occurring in mangroves, have been described [7]. On the other hand, the higher hydrodynamic conditions of the lake entrance and the low organic matter content of these materials avoided the formation and accumulation of the fine clay mineral particles in the southern area of the Sochagota Lake [32].

\subsection{Hydrothermal Inputs and Reduced Microenvironments Favored by Organic Matter}

Isotopic composition of the waters from the Sochagota Lake (mean values of $6.4 \%$ o for $\delta^{34} \mathrm{~S}$ and 8.1 for $\delta^{18} \mathrm{O}$ ) is inside the reference fields indicated in several studies [20,21] for active hydrothermal systems. These data and the absence of evaporitic deposit or any other type of sulfate-bearing rocks in the geological context [16] clearly indicate that sulfur dissolved in the water and precipitated in the materials of the lake is of hydrothermal origin.

S-bearing minerals are concentrated at the organic matter-rich materials from the deeper central and northern part of the lake. Organic matter-rich layers are able to maintain oxygen depleted conditions due to the capability of decaying organic matter to provide electrons for reactions of reduction. In saline environments, such as that of the Sochagota Lake, following the availability of easily degradable organic matter, microorganisms most likely can create microenvironments with reduced Fe and aqueous sulfides in which some processes lead to the precipitation of insoluble sulfides (see, e.g., [33]).

\subsection{The S Cycle in the Materials of the Sochagota Lake}

Figures 4-7 suggest that the presence of S-bearing minerals is not associated to the sediment depth. The main factor controlling the formation of these minerals was the amount of organic matter, which is heterogeneously distributed among both depths (Table 2). Pyrite is the more extended S-bearing mineral from these organic matter-rich materials. This indicates that the uptake of Fe is associated with the existence of S-bearing phases in the materials with finest particles and close to vegetation-rich areas, suggesting the association of a pyritization process to the organic matter abundance. Crystallization of individual pyrite crystals and framboidal aggregates associated with organic matter have been extensively described in anoxic sediments (e.g., [34,35]). For example, nanobacterial cells are frequently found coating pyrite microcrystals associated with decaying organic matter [35]. Pyrite framboids can be formed within templates provided by organic carbon matrix [36]. Experimental studies and field observations suggest that pyrite framboids formation is promoted by the nucleation and growth of iron monosulfides, which are later converted to pyrite (e.g., [37-39]). According to Hu and collaborators, most of the organic matter-rich materials are thought to undergo three processes that contribute to the crystallization of pyrite in framboids [40]: (a) formation and development of precursors (FeS); (b) transformation of $\mathrm{FeS}$ to $\mathrm{FeS}_{2}$; and (c) pyrite growth.

In the materials investigated in this study, high spatial and spectral resolution spectromicroscopy techniques allow to identify textural traces of microorganisms' activity associated with the first stage 
of the framboidal sulfides formation. High-resolution electron microscopy studies are one of the best tools to determine the presence of sulfide nanoparticles, its volume, morphology, composition, and disposition in organic matter-rich environment, allowing to elucidate the importance of the factors controlling its formation, such as the microbial-mineral interactions or the changes in aqueous and sediment chemistry (see, e.g., [14,41,42]). Figure $7 \mathrm{c}-\mathrm{e}$ shows the remarkable morphological and dimensional features of spherical and oval-shaped FeS nanoparticle aggregates in the organic matter-rich sediments of the Sochagota Lake materials, suggesting bacterially induced precipitation of FeS. Raman microspectrometry confirmed the accumulation of these mackinawite particles at the inner part of plant fragments.

Therefore, the FESEM, HRTEM, and Raman microspectrometry data from this study reveal that sulfate-reducing bacteria cells facilitated decisively the uptake of Fe particles from the Sochagota Lake materials through the formation of mackinawite FeS nanoparticles. The experimental study of Picard and collaborators [14] has confirmed the ability of microbial cells to uptake metals (Fe) that concentrate in crusts on the surface of microorganisms as sulfide minerals, suggesting that the cell membrane of sulfate-reducing microorganisms and their extracellular materials can act as templates for the formation and growth of sulfide minerals. Kraal and collaborators [12] suggested that rapid burial under anoxic conditions prevent dissolution of FeS in organic-rich reducing sediments.

Pyrite and $\mathrm{S}^{\circ}$ were likely produced by the alteration of mackinawite produced by a free sulfide excess that generate iron monosulfide dissolution and a later pyrite recrystallization [11,43]. The conversion of monosulfides to pyrite can also be influenced by sulfate-reducing bacteria activity, supplying $\mathrm{H}_{2} \mathrm{~S}$, or organic sulfur able to accept electrons, which facilitate the formation of $\mathrm{FeS}_{2}$ [44-46].

The transformation of sulfide to $S^{\circ}$ by inorganic oxidation reaction is very slowly produced, which suggest that oxidation by microorganisms is the prevalent process for $\mathrm{S}^{\circ}$ crystallization in low-temperature environments [47]. However, Cosmidis and Templeton [48] discovered that $\mathrm{H}_{2} \mathrm{~S}$ can interact with organic matter under an oxygenated environment to form inorganic $\mathrm{S}^{\circ}$, producing filamentous and complex morphologies similar to those observed in the Lago Sochagota materials.

\section{Conclusions}

We have investigated the sedimentary neoformation of S-bearing phases in organic matter-rich sediments from the Sochagota Lake (Colombia), a saline lake in tropical latitude with hydrothermal inputs. The sedimentary processes occurring under saline and reduced conditions carried out the fixation of the hydrothermal sulfur enriched in the water lake.

Most of the materials deposited in the Sochagota Lake are made of detrital quartz and kaolinite. Sediments from the central and northern part of the lake are enriched in neoformed clay minerals (illite and I-DV) by saline transformations due to the interaction with the waters of the lake and high content in organic matter. The isotopic composition of these waters suggest that the sulfur dissolved in these waters is of hydrothermal origin. The hydrothermal input was responsible for the salinity of the waters.

The cycle of sulfur in the lake is related to a pyritization process associated with the abundance of organic matter. The first step of the process was evidenced by FESEM, HRTEM, EDS, and Raman microspectrometry, which revealed the presence of mackinawite particles (sometimes forming cell-shape aggregates) at the inner part of plant fragments of some organic matter-rich cores. The crystallization of mackinawite strongly support that hydrothermal $\mathrm{SO}_{4}{ }^{2-}$ dissolved in the waters of the Sochagota Lake underwent sulfate reduction processes associated with the decay of the organic matter to form S-bearing minerals in the sediments. Microorganisms favored the formation and growth of mackinawite and its transformation to pyrite and $S^{\circ}$. Pyrite was formed by mackinawite alteration in an environment with excess of free sulfide. Filamentous and complex morphologies of $\mathrm{S}^{\circ}$ were formed inorganically by $\mathrm{H}_{2} \mathrm{~S}$ and organic matter reaction in an oxygen-richer environment. 
Author Contributions: C.P.Q. and G.R.C. conducted field observations and sampling. J.J.-M., R.J.-E., C.P.Q., and G.R.C. performed microscopic observations SEM and TEM (mineralogical, textural, chemical analyses, and Raman spectrometry) and interpreted the X-ray diffractograms and TOC. All authors discussed the analytical results and prepared the manuscript. All authors have read and agreed to the published version of the manuscript.

Funding: This work has been financed by the Spanish research project PGC2018-094573-B-I00 from the MCIU-AEIFEDER and research group RNM-325 of the Junta de Andalucía (Spain). Our gratitude is also extended to Asociación Universitaria Iberoamericana de Posgrado (AUIP) and the Universidad de Boyacá. We would also like to thank Colombian Research groups Gestión Ambiental COL0005468 and Gestión de Recursos Hídricos COL0005477.

Acknowledgments: We would like to acknowledge to two anonymous reviewers for their suggestions and comments that helped to improve the manuscript.

Conflicts of Interest: The authors declare no conflict of interest. The funders had no role in the design of the study; in the collection, analyses, or interpretation of data; in the writing of the manuscript; or in the decision to publish the results.

\section{References}

1. Kaasalainen, H.; Stefánsson, A. Sulfur speciation in natural hydrothermal waters, Iceland. Geochim. Cosmochim. Acta 2011, 75, 2777-2791. [CrossRef]

2. Kaasalainen, H.; Stefánsson, A.; Giroud, N.; Arnórsson, S. The geochemistry of trace elements in geothermal fluids, Iceland. App. Geochem. 2015, 62, 207-223. [CrossRef]

3. Björke, J.K.; Stefánsson, A.; Arnórsson, S. Surface water chemistry at Torfajökull, Iceland-Quantification of boiling, mixing, oxidation and water-rock interaction and reconstruction of reservoir fluid composition. Geothermics 2015, 58, 75-86. [CrossRef]

4. Nordstrom, D.K.; McCleskey, R.B.; Ball, J.W. Sulfur geochemistry of hydrothermal waters in Yellowstone National Park: IV Acid-sulfate waters. App. Geochem. 2009, 24, 191-207. [CrossRef]

5. Aghasian, K.; Moridi, A.; Mirbagheri, A.; Abbaspour, M. Selective withdrawal optimization in a multipurpose water use reservoir. Int. J. Environ. Sci. Technol. 2019, 16, 5559-5568. [CrossRef]

6. Zhang, Y.; Liao, J.; Pei, Z.; Lu, X.; Xu, S.; Wang, X. Effect of dam construction on nutrient deposition from a small agricultural karst catchment. Ecol. Indic. 2019, 107. [CrossRef]

7. Cuadros, J.; Andrade, G.; Ferreira, T.O.; Partiti, C.S.M.; Cohen, R.; Vidal-Torrado, P. The mangrove reactor: Fast clay transformation and potassium sink. Appl. Clay Sci. 2017, 140, 50-58. [CrossRef]

8. Ferreira, T.O.; Vidal-Torrado, P.; Otero, X.L.; Macías, F. Are mangrove forest substrates sediments or soils? A case study in southeastern Brazil. Catena 2007, 70, 79-91. [CrossRef]

9. Noël, V.; Boye, K.; Kukkadapu, R.K.; Bone, S.; Pacheco, J.S.L.; Cardarelli, E.; Janot, N.; Fendorf, S.; Williams, K.H.; Bargar, J.R. Understanding controls on redox processes in floodplain sediments of the Upper Colorado River Basin. Sci. Total Environ. 2017, 603-604, 663-675. [CrossRef]

10. Andrade, G.R.P.; Cuadros, J.; Partiti, C.M.S.; Cohen, R.; Vidal-Torrado, P. Sequential mineral transformation from kaolinite to Fe-illite in two Brazilian mangrove soils. Geoderma 2018, 309, 84-99. [CrossRef]

11. Rickard, D.; Luther, G.W. Chemistry of Iron Sulfides. Chem. Rev. 2007, 107, 514-562. [CrossRef]

12. Kraal, P.; Burton, E.D.; Bush, R.T. Iron monosulfide accumulation and pyrite formation in eutrophic estuarine sediments. Geochim. Cosmochim. Acta 2013, 122, 75-88. [CrossRef]

13. Rickard, D.T. Microbial sulfate reduction in sediments. In Developments in Sedimentology: Sulfidic Sediments and Sedimentary Rocks; van Loon, A.J., Ed.; Elsevier: Oxford, UK, 2012; pp. 319-351. [CrossRef]

14. Picard, A.; Gartman, A.; Clarke, D.R.; Girguis, P.R. Sulfate-reducing bacteria influence the nucleation and growth of mackinawite and greigite. Geochim. Cosmochim. Acta 2018, 220, 367-384. [CrossRef]

15. Cosmidis, J.; Nims, C.; Diercks, D.; Templeton, A.S. Formation and stabilization of elemental sulfur through organomineralization. Geochim. Cosmochim. Acta 2019, 247, 59-82. [CrossRef]

16. Pardo, N.; Cepeda, H.; Jaramillo, J.M. The Paipa volcano, Eastern Cordillera of Colombia, South America: Volcanic stratigraphy. Earth Sci. Res. J. 2005, 9, 3-18.

17. Alfaro, C.; Velandia, F.; Cepeda, H. Colombian Geothermal Resources. In Proceedings of the World Geothermal Congress, Antalya, Turkey, 24-29 April 2005; pp. 1-11.

18. Cifuentes, G.R.; Jiménez-Espinosa, R.; Quevedo, C.P.; Jiménez-Millán, J. El ciclo del azufre en sedimentos de lagos con aportes hidrotermales y antrópicos: El Lago Sochagota (Boyacá-Colombia). Macla 2017, 22, 27-28. (In Spanish) 
19. Cifuentes, G.R.; Jiménez-Millán, J.; Quevedo, C.P.; Jiménez-Espinosa, R. Isotopic evidence of the hydrothermal origin of the waters of the Sochagota Lake (Colombia). In Proceedings of the AGU Fall Meeting, San Francisco, CA, USA, 7-11 December 2020.

20. Rye, R.O.; Bethke, P.M.; Wasserman, M.D. The stable isotope geochemistry of acid sulfate alteration. Econ. Geol. 1992, 87, 225-262. [CrossRef]

21. John, D.A.; Lee, R.G.; Breit, G.N.; Dilles, J.H.; Calvert, A.T.; Muffler, L.J.P.; Clynne, M.A. Pleistocene hydrothermal activity on Brokeoff volcano and in the Maidu volcanic center, Lassen Peak area, northeast California: Evolution of magmatic-hydrothermal systems on stratovolcanoes. Geosphere 2019, 15, 946-982. [CrossRef]

22. Sánchez-Roa, C.; Jiménez-Millán, J.; Abad, I.; Faulkner, D.R.; Nieto, F.; García-Tortosa, F.J. Fibrous clay mineral authigenesis induced by fluid-rock interaction in the Galera fault zone (Betic Cordillera, SE Spain) and its influence on fault gouge frictional properties. Appl. Clay Sci. 2016, 134, 275-288. [CrossRef]

23. Sánchez-Roa, C.; Faulkner, D.R.; Boulton, C.; Jimenez-Millan, J.; Nieto, F. How phyllosilicate mineral structure affects fault strength in Mg-rich fault systems. Geophys. Res. Lett. 2017, 44, 5457-5467. [CrossRef]

24. Jiménez-Millán, J.; Abad, I.; García-Tortosa, F.J.; Nieto, F.; Jiménez-Espinosa, R. Clay saline diagenesis in lake Plio-Pleistocene sediments rich in organic matter from the Guadix-Baza Basin (Betic Cordillera, SE Spain). Appl. Clay Sci. 2020, in press.

25. Nieto, F.; Ortega-Huertas, M.; Peacor, D.R.; Arostegui, J. Evolution of illite/smectite from early diagenesis through incipient metamorphism in sediments of the Basque-Cantabrian Basin. Clay Clay Miner. 1996, 44, 304-323. [CrossRef]

26. Guerra, I.; Cardell, C. Optimizing use of the structural chemical analyser (variable pressure FESEM-EDX Raman spectroscopy) on micro-size complex historical paintings characterization. J. Microsc. 2015, 260, 47-61. [CrossRef]

27. Benner, R.; Strom, M. A critical evaluation of the analytical blank associated with DOC measurements by high-temperature catalytic oxidation. Mar. Chem. 1993, 41, 153-160. [CrossRef]

28. Cifuentes, G.R.; Jiménez-Millán, J.; Quevedo, C.P.; Jiménez-Espinosa, R.; Nieto, F. Fijación de K hidrotermal a través de transformaciones secuenciales de formación de illita en ambiente lacustre hipersalino reductor (Lago Sochagota, Colombia). In Sociedad Española de Arcillas 2018; Sociedad Española de Arcillas: Granada, Spain, 2018. (In Spanish)

29. Kleppe, A.K.; Jephcoat, A.P. High-pressure Raman spectroscopic studies of $\mathrm{FeS}_{2}$ pyrite. Mineral. Mag. 2004, $68,433-441$. [CrossRef]

30. Meyer, B. Elemental Sulfur. Chem. Rev. 1976, 76, 367-388. [CrossRef]

31. Bourdoiseau, J.A.; Jeannin, M.; Sabot, R.; Rémazeilles, C.; Refait, P. Characterisation of mackinawite by Raman spectroscopy: Effects of crystallisation, drying and oxidation. Corrosion Sci. 2008, 50, 3247-3255. [CrossRef]

32. Cifuentes, G.R.; Jiménez-Millán, J.; Quevedo, C.P.; Jiménez-Espinosa, R. Low temperature illitization through illite-dioctahedral vermiculite mixed layers in a tropical latitude hypersaline lake rich in hydrothermal fluids (Lago Sochagota, Colombia). In Proceedings of the AGU Fall Meeting, San Francisco, CA, USA, 7-11 December 2020.

33. Smieja-Król, B.; Janeczek, J.; Bauerek, A.; Thorseth, I.H. The role of authigenic sulfides in immobilization of potentially toxic metals in the Bagno Bory wetland, southern Poland. Environ. Sci. Pollut. Res. 2015, 22, 15495-15505. [CrossRef]

34. Love, L.G.; Al-Kaisy, A.T.H.; Brockley, H. Mineral and organic material in matrices and coatings of framboidal pyrite from Pennsylvanian sediments, England. J. Sediment. Res. 1984, 54. [CrossRef]

35. Folk, R.L. Nannobacteria and the formation of framboidal pyrite: Textural evidence. J. Earth Syst. Sci. 2005, 114, 369-374. [CrossRef]

36. MacLean, L.C.W.; Tyliszczak, T.; Gilbert, P.U.P.A.; Zhou, D.; Pray, T.J.; Onstott, T.C.; Southam, G. A highresolution chemical and structural study of framboidal pyrite formed within a low temperature bacterial biofilm. Geobiology 2008, 6, 471-480. [CrossRef] [PubMed]

37. Wilkin, R.; Barnes, H. Formation processes of framboidal pyrite. Geochim. Cosmochim. Acta 1997, 61, 323-339. [CrossRef]

38. Schoonen, M.A.A. Mechanisms of sedimentary pyrite formation. Geol. Soc. Am. Spec. Pap. 2004, 379, 117-134. 
39. Ohfuji, H.; Rickard, D. High resolution transmission electron microscopic study of synthetic nanocrystalline mackinawite. Earth Planet. Sci. Lett. 2006, 241, 227-233. [CrossRef]

40. Hu, S.Y.; Evans, K.; Fisher, L.; Rempel, K.; Craw, D.; Evans, N.J.; Cumberland, S.; Robert, A.; Grice, K. Associations between sulfides, carbonaceous material, gold and other trace elements in polyframboids: Implications for the source of orogenic gold deposits, Otago Schist, New Zealand. Geochim. Cosmochim. Acta 2016, 180, 197-213. [CrossRef]

41. Cosmidis, J.; Benzerara, K.; Menguy, N.; Arning, E. Microscopy evidence of bacterial microfossils in phosphorite crusts of the Peruvian shelf: Implications for phosphogenesis mechanisms. Chem. Geol. 2013, 359, 10-22. [CrossRef]

42. Xu, J.; Murayama, M.; Roco, C.M.; Veeramani, H.; Michel, F.M.; Rimstidt, J.D.; Winkler, C.; Hochella, M.F.J. Highly-defective nanocrystals of $\mathrm{ZnS}$ formed via dissimilatory bacterial sulfate reduction: A comparative study with their abiogenic analogues. Geochim. Cosmochim. Acta 2016, 180, 1-14. [CrossRef]

43. Rickard, D.; Grimes, S.T.; Butler, I.; Oldroyd, A.; Davies, K.L. Botanical constraints on pyrite formation. Chem. Geol. 2007, 236, 228-246. [CrossRef]

44. Nabbefeld, B.; Grice, K.; Schimmelmann, A.; Sauer, P.E.; Böttcher, M.E.; Twitchett, R. Significance of $\delta D$ kerogen, $\delta^{13} \mathrm{C}, \delta^{13} \mathrm{C}_{\text {kerogen }}$ and $\delta^{34} \mathrm{~S}_{\text {pyrite }}$ from several Permian/Triassic (P/Tr) sections. Earth Planet. Sci. Lett. 2010, 295, 21-29. [CrossRef]

45. Jaraula, C.M.; Grice, K.; Twitchett, R.J.; Böttcher, M.E.; LeMetayer, P.; Dastidar, A.G.; Opazo, L.F. Elevated $\mathrm{pCO}_{2}$ leading to Late Triassic extinction, persistent photic zone euxinia, and rising sea levels. Geology 2013, 41, 955-958. [CrossRef]

46. Melendez, I.; Grice, K.; Schwark, L. Exceptional preservation of Palaeozoic steroids in a diagenetic continuum. Sci. Rep. 2013, 3. [CrossRef] [PubMed]

47. Luther, G.W.; Findlay, A.; MacDonald, D.J.; Owings, S.M.; Hanson, T.E.; Beinart, R.A.; Girguis, P.R. Thermodynamics and kinetics of sulfide oxidation by oxygen: A look at inorganically controlled reactions and biologically mediated processes in the environment. Front. Microbiol. 2011, 2, 62. [CrossRef] [PubMed]

48. Cosmidis, J.; Templeton, A.S. Self-assembly of biomorphic carbon/sulfur microstructures in sulfidic environments. Nat. Commun. 2016, 7, 12812. [CrossRef] [PubMed] 